\title{
OBSERVATIONS ON THE PATHOGENIC PROPERTIES OF THE K88, HLY AND ENT PLASMIDS OF ESCHERICHIA COLI WITH PARTICULAR REFERENCE TO PORCINE DIARRHOEA
}

\author{
H. Williams Smith* and Margaret A. Linggood \\ Animal Health Trust, Stock, Essex
}

ONE characteristic common to enteropathogenic strains of Escherichia coli of porcine origin is the ability to produce enterotoxin. A large proportion of these strains also produce $\alpha$-haemolysin. Many possess a common $\mathrm{K}$ antigen, K88ab or ac, in addition to the one by which $E$. coli are usually classified. In some enteropathogenic strains, enterotoxin, haemolysin and K88 production are known to be governed by transmissible plasmids, designated Ent (Smith and Halls, 1968a), Hly (Smith and Halls, 1967) and K88 (Ørskov and Ørskov, 1966) respectively, in the same manner as are antibiotic resistance ( $\mathrm{R}$ factors) and colicine production ( $\mathrm{Col})$.

By plasmid transmission and by "curing" with cytoplasmic poisons (Watanabe, 1963), we created strains of $E$. coli that differed only in regard to the particular combination of the Ent, Hly and K88 plasmids they possessed. We then used them in infection experiments with the object of determining the part played by enterotoxin, haemolysin and K88 antigen in the pathogenesis of $E$. coli diarrhoea in the pig. The results of these experiments are reported in this paper. So are some of the more general pathological effects of haemolysin and the K88 antigen in mice and pigs; those of enterotoxin have been reported previously (Smith and Halls, 1968a).

\section{MATERIALS AND METHODS}

Transfer of Ent, Hly and K88 plasmids. Essentially the same technique was employed for transferring all three plasmids, the basic principle being to grow donor and recipient organisms together in nutrient broth for conjugation and plasmid transfer to occur and then to culture on media that suppressed the donor organisms and, if possible, permitted the identification of those recipient organisms that had acquired the character under study.

Ent transfer. This was performed by the method of Smith and Halls (1968a), the recipient strains being mutants resistant to streptomycin or sodium nalidixate. The mixed culture of donor and recipient organisms, after incubation at $37^{\circ} \mathrm{C}$ for $24 \mathrm{hr}$, was subcultured twice in broth containing streptomycin or sodium nalidixate, to eliminate donor organisms, and then once in plain broth. This final culture was submitted to the ligated-intestine test in a pig. If it produced dilatation, cultures of colonies obtained from the final culture were also tested. Those that produced dilatation were designated Ent ${ }^{+}$and those that did not, Ent ${ }^{-}$. The Ent status of wild strains used in this work was also determined by the ligated-intestine

Received 19 Mar. 1971; accepted 7 June 1971.

* Present address: A.R.C. Poultry Research Institute, Houghton, Huntingdon. Requests for reprints should be sent to H.W.S. at that address.

J. MED. MICROBIOL.-VOL. 4 (1971) 
test. Those that failed to dilate ligated intestinal segments of weaned pigs, the kind of pigs normally used in these tests, were tested in ligated segments of intestine of piglets a few days old before being finally classified as Ent ${ }^{-}$. This was done because Moon and Whipp (1970) had reported three strains of $E$. coli that dilated intestinal segments of very young pigs but not of weaned pigs.

Hly and K88 transfer. The method of Smith and Halls (1967) for demonstrating Hly transfer was employed. Wherever possible, mutants resistant to sodium nalidixate or streptomycin were used as recipients; the mixed culture of donor and recipient, after incubation at $37^{\circ} \mathrm{C}$ for $24 \mathrm{hr}$, was inoculated so as to yield as many as possible well-isolated colonies on "washed blood" agar containing sodium nalidixate or streptomycin. The plates were incubated at $37^{\circ} \mathrm{C}$ for $24 \mathrm{hr}$ and any colonies that were haemolytic or agglutinated in slide tests with serum containing antibodies to $\mathrm{K} 88$ antigen, or had both properties, were removed for purification and further identification. Occasionally, when K88 transfer only was being attempted, nutrient agar or MacConkey's agar was employed instead of "washed blood" agar. When the donor organisms contained an $\mathrm{R}$ factor, the selection of $\mathrm{Hly}+$ or $\mathrm{K}^{+} 8^{+}$ recipient organisms was often facilitated by incorporating the antibiotic to which the donor was resistant in the solid medium on to which the mixed culture was inoculated. Although the Hly and $\mathrm{K} 88$ plasmids were not linked to the $\mathrm{R}$ factor, this procedure did at least ensure that all the colonies growing on this medium had originated from organisms that had conjugated during mixed culture. Sometimes it was necessary to introduce Hly or K88 into an antibiotic-sensitive strain instead of into a resistant mutant. This was facilitated by using a donor readily distinguishable from the recipient by its colonial morphology or its fermentative ability.

The removal of $\mathrm{Hly}$ and $\mathrm{K} 88$ plasmids from strains containing them. Sometimes, Hlystrains could be obtained from Hly + ones simply by inoculating them on plates of "washed blood" agar and, after incubation, searching for non-haemolytic colonies. In a similar manner, $\mathrm{K} 88$ - strains were occasionally obtained from $\mathrm{K} 88^{+}$ones by testing a large number of colonies with $\mathrm{K} 88$ antiserum. If $\mathrm{Hly}^{-}$or $\mathrm{K88}$ - strains could not be obtained by this procedure, the cultures were subcultured one or more times in broth containing concentrations of acridine orange (Hirota, 1960) that markedly inhibited their growth rate before being inoculated on the plates of media. This procedure was also used in attempts to obtain Ent ${ }^{-}$strains from Ent ${ }^{+}$ones, cultures of colonies that grew on the plates of media being tested for Ent by submitting them to the ligated-intestine test. So were other techniques found to be useful in obtaining plasmid-free organisms. These included culture in broth containing ethidium bromide (Bouanchaud, Scavizzi and Chabbert, 1969) and sodium lauryl sulphate (Tomoeda et al., 1968). Success was never attained.

Experimental infections in pigs. All the pigs used belonged to a small self-contained herd constituted from one litter obtained from another herd whose pigs had been found to be susceptible to $E$. coli infection (Smith and Halls, 1968b). This breeding herd was managed according to ordinary commercial practice. The females were moved into well-cleaned and disinfected farrowing pens shortly before parturition and their litters spent their first few weeks of life in them. The piglets' diet was supplemented with solid food, the amount provided increasing with age, each piglet receiving about $250-350 \mathrm{~g}$ per day when weaned at $8 \mathrm{wk}$ of age. At weaning, the piglets were placed in groups in portable metal pens with solid sides and given 500-800 g of food per day. Between experiments, the pens were sterilised with a blow-lamp and moved to a new site. Some piglets were removed from their mothers before they had consumed colostrum. These were kept in heated boxes and given $25-40 \mathrm{ml}$ of suitably diluted sterile cows' milk every $4-6 \mathrm{hr}$ by stomach tube. They are always referred to in the text as colostrum-deprived. All the naturally reared piglets that were used in infection experiments had been born to primigravid mothers. This policy was adopted because they were more susceptible to $E$. coli infection than were the progeny of multigravid females. The latter were either used colostrum-deprived or when they were weaned.

Inoculation method. Piglets were usually infected between 6 and $24 \mathrm{hr}$ of birth by placing in the back of their mouths $1 \mathrm{ml}$ of a nutrient broth culture that had been incubated at $37^{\circ} \mathrm{C}$ for $24 \mathrm{hr}$. Weaned pigs were infected within a few days of being removed from their mothers 
when 8 wk old. A nutrient agar slope inoculated with the culture under study was incubated at $37^{\circ} \mathrm{C}$ for $18 \mathrm{hr}$ and the bacterial growth washed off with phosphate buffer, $p \mathrm{H} 7 \cdot 0$ $\left(\mathrm{Na}_{2} \mathrm{HPO}_{4}, 1.5 \mathrm{~g} ; \mathrm{KH}_{2} \mathrm{PO}_{4}, 0.85 \mathrm{~g} ; \mathrm{H}_{2} \mathrm{O}, 1\right.$ litre $)$ and adjusted to contain approximately 1010 viable organisms in $5 \mathrm{ml}$. This amount was placed in the back of the mouth of each pig. If several litters had to be used in any one experiment, each litter, wherever possible, was divided according to the total number of groups required for that experiment.

The examination of pigs after inoculation. After inoculation, the health status of each pig was assessed several times daily. Usually, a specimen of faeces was removed from the rectum once daily and the concentration of viable organisms of the infecting strain of $E$. coli present was estimated by the method of Miles and Misra (Miles, Misra and Irwin, 1938). This was facilitated by using blood agar as the culture medium; most experimental strains were haemolytic. The identity of a representative sample of the haemolytic colonies growing on the blood agar was confirmed by slide agglutination tests with appropriate antisera. Because of the quantitative changes in the bacterial flora of the intestine that take place soon after death (Smith, 1962; Smith and Jones, 1963), all severely ill pigs were watched

TABLE I

The effect of giving day-old piglets by mouth forms of the Escherichia coli O141:K85ab, $88 a b$ strain possessing different combinations of the Hly and K88 plasmids

\begin{tabular}{l|c|c|c}
\hline \multirow{2}{*}{ Form of strain } & \multicolumn{3}{|c}{ Number of piglets } \\
\cline { 2 - 4 } & $\begin{array}{c}\text { to which it } \\
\text { was given }\end{array}$ & $\begin{array}{c}\text { that developed } \\
\text { diarrhoea }\end{array}$ & that died $\dagger$ \\
\hline Hly $^{+}{\mathrm{K} 88^{+}}^{+}$ & 10 & 10 & 5 \\
$\mathrm{Hly}^{-} \mathrm{K} 88^{+}$ & 10 & 9 & 5 \\
$\mathrm{Hly}^{+} \mathrm{K} 88^{-}$ & 13 & 0 & 0 \\
\hline
\end{tabular}

* The $\mathrm{Hly}^{+} \mathrm{K} 88^{-}$- form into which a $\mathrm{K} 88 \mathrm{ab}$ plasmid had been introduced from another strain of E. coli.

$\dagger$ or were killed when severely ill.

carefully and, when death was imminent, they were killed by intracardiac injection of pentobarbitone sodium; other pigs whose alimentary flora was also to be studied were killed in the same manner. The abdomen was opened quickly and ligatures were applied to the duodenum close to the stomach, to the ileo-caecal junction and at numerous points along the small intestine. The whole alimentary tract was then removed and unravelled; the small intestine was arranged into seven equal parts and the ligatures not needed to separate these parts were removed. The contents of the stomach and of each part of the small intestine, the colon and the rectum were removed and their $E$. coli content estimated in the same manner as it had been estimated in the faeces at the daily examinations. Strains resistant to different antibiotics were used, whenever possible, when dual infections were produced in pigs. Their concentrations in the contents of the alimentary tract could then be estimated by using two sets of culture plates for counting, each containing $20 \mu \mathrm{g}$ per ml of a different antibiotic.

\section{RESULTS}

The significance of the Hly and K88 plasmids in the ability of an O141:K85ab,88ab strain of E. coli to infect pigs

The results of giving naturally reared 1-day-old piglets, by mouth, this wild enteropathogenic strain of $E$. coli possessing both the Hly and K88 
plasmids, or forms of it from which one or other of these plasmids had been eliminated, are summarised in table I; so are the results of giving the K88- $\mathrm{Hly}+$ form after the introduction of another K88ab plasmid. The new plasmid was present originally in a wild enteropathogenic strain of antigenic structure $\mathrm{O} 8: \mathrm{K} 87,88 \mathrm{ab}$. It was transferred from this strain to a non-pathogenic strain before being ultimately introduced into the $\mathrm{K} 88-\mathrm{Hly}+$ form. This indirect method was adopted to lessen the possibility of other genetic material being transferred at the same time as the K88 plasmid. Media containing antibiotics could not be used to suppress donor organisms during these K88 transfer experiments because the O141 strain itself was antibiotic-sensitive. As judged by the amount of fluid that accumulated in ligated segments of pig intestine into which the $\mathrm{K} 88+\mathrm{Hly}^{+}, \mathrm{K} 88-\mathrm{Hly}+, \mathrm{K} 88+\mathrm{Hly}$ - and $\mathrm{K} 88$ - Hly-forms of the 0141 strain had been injected, these four forms did not differ in regard to enterotoxin production.

Table I shows that the incidence and severity of diarrhoea in the piglets given the $\mathrm{Hly}-\mathrm{K} 88+$ form of the $\mathrm{O} 141$ strain equalled that produced by the wild strain itself, i.e., the $\mathrm{Hly}+\mathrm{K} 88+$ form. By contrast, the piglets given the $\mathrm{Hly}+\mathrm{K} 88$ - form remained normal and, unlike the diarrhoeic piglets, usually had only comparatively low concentrations of the infecting strain in their faeces. The disease in the piglets given the $\mathrm{Hly}+\mathrm{K} 88-\mathrm{K} 88+$ form, i.e., the $\mathrm{Hly}+\mathrm{K} 88-$ form into which a K88ab plasmid had been introduced, resembled that in the piglets given the wild strain itself. The diarrhoea in all the affected piglets was very severe and commenced 12-24 hr after infection. A few of the piglets given the $\mathrm{Hly}+\mathrm{K} 88$ - form showed signs of diarrhoea some 3 days after infection, but this was always due to cross-infection with a $\mathrm{K} 88+$ form from littermate piglets that had been given it. The results of estimating the numbers of $E$. coli in the alimentary tract of two piglets given the $\mathrm{Hly}+\mathrm{K} 88$ - form and in another two given the $\mathrm{Hly}-\mathrm{K} 88+$ or the Hly $+\mathrm{K} 88-\mathrm{K} 88+$ form are shown in table II. Very high concentrations of the infecting organisms were found in the chyme in the small intestine of the latter two piglets and very low concentrations in this region in the other two piglets, although in one of them there were moderately high concentrations of $\mathrm{Hly}+\mathrm{K} 88+$ organisms that it had acquired as a result of cross-infection. No E. coli were found in the liver and spleen of these four piglets.

The results of giving the differentforms of the 0141 strain to 8-wk-old weaned pigs (table III) were essentially the same as those obtained in the piglets. A large group was given the Hly- $\mathrm{K} 88+$ form in the hope of discovering whether the Hly plasmid was playing a part in the pathogenesis of the disease, but no detectable difference was found between this group and the group given the $\mathrm{Hly}+\mathrm{K} 88+$ form. Two pigs were given mixtures of equal amounts of the $\mathrm{Hly}+\mathrm{K} 88+$ and $\mathrm{Hly}-\mathrm{K} 88+$ forms. Both developed diarrhoea and the concentrations of the two forms found in their faeces at the daily examinations were approximately the same. So were the numbers in the different parts of their alimentary tract when they were killed during the diarrhoeic phase of the disease. The results for one of these pigs are illustrated in table IV. So are those for four pigs given one or other of four different forms of the 0141 
strain. None of the infecting organisms was found in the pig that had been given the $\mathrm{Hly}+\mathrm{K} 88$ - form, but high concentrations were found in the alimentary tract of the pig, from the same litter, that had been given the $\mathrm{Hly}+\mathrm{K} 88^{-}$

TABLE II

The concentration of the infecting organisms in different parts of the alimentary tract of piglets given by mouth forms of the Escherichia coli O141:K85ab,88ab strain possessing different combinations of the Hly and K88 plasmids

\begin{tabular}{l|c|c|c|c}
\hline \multirow{2}{*}{ Organ } & \multicolumn{3}{|c}{$\log _{10}$ number of infecting organisms per gof content of stated organ, } \\
in a piglet given the
\end{tabular}

* The small intestine was divided into seven equal parts for counting: level 1 was nearest to the stomach and level 7 to the caecum.

$\dagger$ The figures in parentheses are those for an $\mathrm{Hly}^{+}{\mathrm{K} 88^{+}}^{+}$form of the 0141 strain which this piglet had acquired naturally from other littermate piglets that had been given it.

The $\mathrm{Hly}^{+}{\mathrm{K} 88^{-}}^{-} \mathrm{K} 88^{+}$form was the $\mathrm{Hly}^{+} \mathrm{K} 88^{-}$form into which a $\mathrm{K} 88 \mathrm{ab}$ plasmid had been introduced from another strain. The pig given this form and the one given the $\mathrm{Hly}^{-} \mathrm{K} 88^{+}$form had severe diarrhoea; the other two were normal.

\section{TABLE III}

The effect of giving weaned 8-wk-old pigs, by mouth, forms of the Escherichia coli O141:K85ab, 88 ab strain possessing different combinations of the Hly and K88 plasmids

\begin{tabular}{l|c|c|c}
\hline \multirow{2}{*}{ Form of strain } & \multicolumn{3}{|c}{ Number of pigs } \\
\cline { 2 - 4 } & $\begin{array}{c}\text { to which it } \\
\text { was given }\end{array}$ & $\begin{array}{c}\text { that developed } \\
\text { diarrhoea }\end{array}$ & that died \\
\hline $\mathrm{Hly}^{+}{\mathrm{K} 88^{+}}^{+}$ & 12 & 12 & 4 \\
$\mathrm{Hly}^{-} \mathrm{K}^{+}$ & 18 & 16 & 4 \\
$\mathrm{Hly}^{+} \mathrm{K} 88^{-}$ & 2 & 0 & 0 \\
\hline
\end{tabular}

For abbreviations see table I.

$\mathrm{K} 88+$ form. Very high concentrations of the infecting organisms were found in the two pigs given either the $\mathrm{Hly}+\mathrm{K} 88+$ or the $\mathrm{Hly}-\mathrm{K} 88+$ form. These two pigs, severely ill when killed, were members of a litter that appeared 
unusually susceptible to severe $E$. coli infection. No $E$. coli organisms were found in the liver and spleen of any of the pigs used in these experiments.

\section{The significance of the $\mathrm{Hly}^{+}$plasmid in the ability of an O141:K85ac strain of E. coli to infect pigs}

Five weaned pigs were infected with a wild haemolytic O141:K85ac strain of $E$. coli, a strain known to cause oedema disease frequently (Smith and Halls, 1968b). Another five were given an $\mathrm{Hly}^{-}$form of this strain and another

\section{TABLE IV}

The concentration of the infecting organisms in different parts of the alimentary tract of weaned pigs given by mouth forms of the Escherichia coli O141:K85ab,88ab strain possessing different combinations of the Hly and K88 plasmids

\begin{tabular}{|c|c|c|c|c|c|}
\hline \multirow[b]{2}{*}{ Organ } & \multicolumn{5}{|c|}{$\begin{array}{l}\log _{10} \text { number of infecting organisms per } g \text { of content of stated organ, } \\
\text { in a pig given the }\end{array}$} \\
\hline & $\begin{array}{l}\mathrm{Hly}^{+} \mathrm{K}^{+} 8^{+} \\
\text {form* }\end{array}$ & $\begin{array}{l}\text { Hly }{ }^{-} \mathrm{K}_{8}+ \\
\quad \text { form* }\end{array}$ & $\begin{array}{c}\mathrm{Hly}^{+} \mathrm{K}^{2} 88^{+} \\
\text {and Hly } \mathrm{K}^{-} 88^{+} \\
\text {forms in equal } \\
\text { numbers* }\end{array}$ & $\begin{array}{l}\mathrm{Hly}{ }^{+} \mathrm{K} 88^{-} \\
\text {form }\end{array}$ & $\begin{array}{l}\mathrm{Hly}+\mathrm{K}^{+} 8^{-} \\
\mathrm{K}^{-} 8^{+} \\
\text {form* }\end{array}$ \\
\hline Stomach & $5 \cdot 0$ & $4 \cdot 7$ & $<2 \cdot 7:<2 \cdot 7$ & $<2 \cdot 7$ & $2 \cdot 7$ \\
\hline $\begin{array}{c}\text { Small intestine } \\
\text { at level } \\
1 \\
3 \\
5 \\
7\end{array}$ & $\begin{array}{l}7 \cdot 3 \\
8 \cdot 5 \\
9 \cdot 0 \\
9 \cdot 7\end{array}$ & $\begin{array}{l}7 \cdot 3 \\
8 \cdot 6 \\
9 \cdot 3 \\
9 \cdot 7\end{array}$ & $\begin{array}{ll}5 \cdot 4: & 5 \cdot 6 \\
6 \cdot 3 \vdots & 6 \cdot 3 \\
8 \cdot 5 \vdots & 8 \cdot 7 \\
9 \cdot 3 \vdots & 9 \cdot 4\end{array}$ & $\begin{array}{l}<2.7 \\
<2.7 \\
<2.7 \\
<2.7\end{array}$ & $\begin{array}{l}5 \cdot 3 \\
5 \cdot 5 \\
7 \cdot 6 \\
8 \cdot 3\end{array}$ \\
\hline Colon & $8 \cdot 6$ & $9 \cdot 5$ & $8 \cdot 5: \quad 8 \cdot 3$ & $<2.7$ & $7 \cdot 5$ \\
\hline Rectum & $9 \cdot 3$ & $9 \cdot 7$ & $8 \cdot 5: \quad 8 \cdot 3$ & $<2 \cdot 7$ & $8 \cdot 5$ \\
\hline
\end{tabular}

For abbreviations see table II.

* The two pigs given either the $\mathrm{Hly}^{+} \mathrm{K}^{*} 8^{+}$or the $\mathrm{Hly}-\mathrm{K} 88^{+}$form were extremely ill. They were from a different litter than the other pigs. The pig given the $\mathrm{Hly}^{+} \mathrm{K} 88^{-}$- form was normal, and the other two had diarrhoea with no constitutional disturbances.

$\dagger$ The numbers of $\mathrm{Hly}^{+} \mathrm{K} 88^{+}$organisms are given first and the numbers of $\mathrm{Hly}-\mathrm{K} 88^{+}$organisms second.

six an $\mathrm{Hly}^{-} \mathrm{Hly}+$ form, i.e., the $\mathrm{Hly}^{-}$form after an Hly plasmid had been introduced into it from a non-pathogenic strain of $E$. coli. At the daily postinfection examinations, high concentrations of the infecting organisms were found in the faeces of all 16 pigs, the concentrations, in general, being somewhat lower in those given the Hly - form than in those given the other forms. Three of the pigs given the Hly - form developed diarrhoea and two of them died from oedema disease. All the pigs in the other two groups developed diarrhoea and three from each group died. 
The significance of the Ent and K88 plasmids in the ability of an O8:K40,88ab:H9 strain of E. coli to infect pigs

A non-haemolytic O8:K40,88ab:H9 strain was included in these studies because it had been found in abnormally high concentrations in the small

TABLE V

The effect of giving piglets, by mouth, forms of an Escherichia coli $08: K 40,88 a b: H 9$ strain possessing different combinations of the K88 and Ent plasmids

\begin{tabular}{c|c|c}
\hline \multirow{2}{*}{ Form of strain } & \multicolumn{2}{|c}{ Number of piglets } \\
\cline { 2 - 3 } & to which it was given & that developed diarrhoea \\
\hline $\mathrm{K} 88^{+} \mathrm{Ent}^{-}$ & 9 & 3 \\
$\mathrm{~K} 88^{+} \mathrm{Ent}^{+}$ & 9 & 8 \\
$\mathrm{~K} 88^{-} \mathrm{Ent}^{+}$ & 5 & 0 \\
\hline
\end{tabular}

intestine of a diarrhoeic piglet, but had not given a positive reaction in the ligated-intestine test in pigs and in piglets. An Ent plasmid was introduced into it from an enteropathogenic strain of $E$. coli of antigenic structure

TABLE VI

The concentration of the infecting organisms in different parts of the alimentary tract of piglets given, by mouth, forms of the Escherichia coli O8:K40,88ab:H9 strain possessing different combinations of the K88 and Ent plasmids

\begin{tabular}{|c|c|c|c|}
\hline \multirow{2}{*}{ Organ } & \multicolumn{3}{|c|}{$\begin{array}{c}\log _{10} \text { number of infecting organisms per } g \text { content of stated } \\
\text { organ, in a piglet given the }\end{array}$} \\
\hline & $\mathrm{K}^{2} 8^{+} \mathrm{Ent}^{-}$form* & $\mathrm{K} 88^{+} \mathrm{Ent}^{+}$form & $\mathrm{K} 88^{-} \mathrm{Ent}^{+}$form \\
\hline Stomach & $5 \cdot 7$ & $6 \cdot 3$ & $4 \cdot 8$ \\
\hline $\begin{array}{c}\text { Small intestine at level } \\
1 \\
3 \\
5 \\
7\end{array}$ & $\begin{array}{l}8 \cdot 3 \\
9 \cdot 3 \\
9 \cdot 8 \\
9 \cdot 3\end{array}$ & $\begin{array}{r}9 \cdot 3 \\
9 \cdot 3 \\
9 \cdot 8 \\
10 \cdot 2\end{array}$ & $\begin{array}{l}4 \cdot 4 \\
5 \cdot 6 \\
5 \cdot 6 \\
6 \cdot 0\end{array}$ \\
\hline Colon & $9 \cdot 6$ & 9.9 & $6 \cdot 9$ \\
\hline
\end{tabular}

For abbreviations see table II.

* The piglet given the K88- $\mathrm{Ent}^{+}$form was normal. The other two piglets had diarrhoea; it was severest in the one given the $\mathrm{K} 88^{+} \mathrm{Ent}+$ form.

O8:K87,88ab. The K88 plasmid was removed from the Ent ${ }^{+}$form, three forms then being available for study, a $\mathrm{K} 88+\mathrm{Ent}^{-}$, a $\mathrm{K} 88+\mathrm{Ent}^{+}$, and a $\mathrm{K} 88$ - Ent + form.

The results of giving cultures of the three forms to naturally reared young piglets are summarised in table $\mathrm{V}$. All the piglets given the $\mathrm{K} 88-\mathrm{Ent}^{+}$form 
remained healthy. Diarrhoea occurred more commonly and was more severe in the piglets given the $\mathrm{K} 88+\mathrm{Ent}+$ form than in those given the $\mathrm{K} 88+\mathrm{Ent}-$ form. The number of piglets that died is not shown in table $\mathrm{V}$ because many of those with diarrhoea were killed before death was imminent so that their alimentary tracts could be examined bacteriologically. The results of examining three piglets from the same litter are shown in table VI. These piglets were killed when the two given the $\mathrm{K} 88$ + Ent + form or the $\mathrm{K} 88$ + Ent - form had had diarrhoea for at least $12 \mathrm{hr}$, the one given the $\mathrm{K} 88+\mathrm{Ent}+$ form being near to death. E. coli was not isolated from the livers or spleens of these piglets. Very high concentrations of the infecting organisms were found throughout the small intestine of the piglets given the $\mathrm{K} 88+$ Ent + and $\mathrm{K} 88+$ Ent - forms; very much lower concentrations were found in the piglet given the $\mathrm{K} 88-\mathrm{Ent}{ }^{+}$form. Similar results were obtained in examining other piglets given these three forms.

\section{The effect of the introduction of the Ent and K88 plasmids on the ability of a non-pathogenic O9:K36:H19 strain of E. coli to infect piglets}

This non-haemolytic strain had been isolated initially from the faeces of a healthy pig. It did not dilate ligated intestinal segments of pigs or young piglets, neither did it cause clinical disease in them after oral administration. Although some strains possessing the $\mathrm{O} 9$ antigen can cause diarrhoea in pigs, none possessing the K36 and H19 antigens has been reported as being able to do so.

To facilitate the introduction of plasmids, a streptomycin-resistant mutant of the 09:K36:H19 strain was used. A K88ac plasmid was introduced from an O8:K87,88ac strain of E. coli and an Ent plasmid from an O8:K87, $88 \mathrm{ab}$ strain. Plasmids determining haemolysin production, colicine production and neomycin resistance were transferred with the K88 plasmid. After removal of the K88 plasmid, four forms of the O9:K36:H19 strain, $\mathrm{K}_{88}{ }^{+} \mathrm{Ent}^{+}$, $\mathrm{K}_{88}+\mathrm{Ent}^{-}, \mathrm{K} 88-\mathrm{Ent}^{+}$and K88- Ent ${ }^{-}$, were available for study. All four were $\mathrm{Hly}+\mathrm{Neo}^{+} \mathrm{Col}^{+}$and, of course, str ${ }^{\mathrm{r}}$. In some experiments, piglets were given cultures of one or other of these forms together with cultures of a nalidixic acid-resistant mutant of the original $09: \mathrm{K} 36: \mathrm{H} 19$ strain. The numbers of each in the alimentary contents of the piglets could easily be estimated by performing the counts in duplicate on medium containing sodium nalidixate and on medium containing streptomycin. The colicine was a very weak one. It was active against $E$. coli $\mathrm{K} 12$, but not against the $09: \mathrm{K} 36: \mathrm{H} 19$ strain. In mixed culture, cultures of $\mathrm{Col}^{-} \mathrm{O} 9: \mathrm{K} 36: \mathrm{H} 19$ organisms grew at the same rate as $\mathrm{Col}^{+}$ones.

The results of giving the four forms to naturally reared piglets are summarised in table VII. All the piglets given the K88-Ent - and K88-Ent ${ }^{+}$forms remained healthy. Diarrhoea occurred more commonly in the piglets given the $\mathrm{K} 88+\mathrm{Ent}^{+}$form than in those given the $\mathrm{K} 88+\mathrm{Ent}-$ form. It was also more severe in the piglets given the $\mathrm{K} 88+\mathrm{Ent}+$ form. For example, both of two piglets in one litter died within $24 \mathrm{hr}$ of being given this form, whereas the three given the $\mathrm{K} 88+\mathrm{Ent}-$ form, although diarrhoeic, did not. Eighteen of the 
piglets were killed in order to determine the concentrations of E. coli organisms in their alimentary tracts, the reason for the death rates not being shown in table VII. Low concentrations of the infecting organisms were found in the

TABLE VII

The effect of giving piglets, by mouth, forms of an Escherichia coli O9:K36:H19 strain possessing different combinations of the K88 and Ent plasmids

\begin{tabular}{|c|c|c|}
\hline \multirow{2}{*}{ Form of strain* } & \multicolumn{2}{|c|}{ Number of piglets } \\
\hline & to which it was given & that developed diarrhoea \\
\hline $\begin{array}{l}\text { K88- Ent } \\
\text { K88- } \\
\text { K8nt } \\
\text { K88 } 8^{+} \text {Ent }^{-} \\
\text {K88 } \\
\text { Ent }\end{array}$ & $\begin{array}{r}8 \\
6 \\
11 \\
16\end{array}$ & $\begin{array}{r}0 \\
0 \\
3 \\
12\end{array}$ \\
\hline
\end{tabular}

* All forms possessed plasmids for haemolysin production and colicine production and for resistance to neomycin.

small intestines of piglets given the $\mathrm{K} 88-\mathrm{Ent}-$ and $\mathrm{K} 88-\mathrm{Ent}+$ forms and high concentrations in those given the $\mathrm{K} 88+$ Ent - and $\mathrm{K} 88+\mathrm{Ent}+$ forms. The results for four of these piglets are given in table VIII. One of them given the

TABLE VIII

The concentration of the infecting organisms in different parts of the alimentary tract of piglets given by mouth forms of the Escherichia coli O9:K36:H19 strain possessing different combinations of the K88 and Ent plasmids

\begin{tabular}{|c|c|c|c|c|}
\hline \multirow{2}{*}{ Organ } & \multicolumn{4}{|c|}{$\begin{array}{l}\log _{10} \text { number of infecting organisms per } g \text { content of stated organ, } \\
\text { in a piglet given the }\end{array}$} \\
\hline & $\begin{array}{l}\text { K88- Ent- } \\
\text { form }\end{array}$ & $\begin{array}{l}\mathrm{K} 88^{+} \mathrm{Ent}^{-} \\
\text {form }(1)^{*}\end{array}$ & $\begin{array}{l}\mathrm{K} 88^{+} \mathrm{Ent}^{-} \\
\text {form }(2)^{*}\end{array}$ & $\begin{array}{l}\mathrm{K} 88^{+} \mathrm{Ent}^{+} \\
\text {form }\end{array}$ \\
\hline Stomach & $5 \cdot 3$ & $4 \cdot 0$ & $3 \cdot 4$ & $5 \cdot 7$ \\
\hline $\begin{array}{c}\text { Small intestine at level } \\
1 \\
3 \\
5 \\
7\end{array}$ & $\begin{array}{l}5 \cdot 3 \\
6 \cdot 0 \\
4 \cdot 7 \\
7 \cdot 4\end{array}$ & $\begin{array}{r}8 \cdot 3 \\
8 \cdot 6 \\
8 \cdot 5 \\
10 \cdot 2\end{array}$ & $\begin{array}{l}5 \cdot 2 \\
8 \cdot 7 \\
8 \cdot 3 \\
9 \cdot 2\end{array}$ & $\begin{array}{l}9 \cdot 5 \\
9 \cdot 3 \\
9 \cdot 2 \\
9 \cdot 2\end{array}$ \\
\hline Colon & $8 \cdot 4$ & $9 \cdot 7$ & $9 \cdot 2$ & $9 \cdot 5$ \\
\hline
\end{tabular}

For abbreviations see table II.

* The results for two piglets given the $\mathrm{K}^{8} 8^{+} \mathrm{Ent}^{-}$form are shown; piglet (1) was ill, but never had diarrhoea, whereas piglet (2), like the one given the $\mathrm{K}^{8} 8^{+} \mathrm{Ent}^{+}$form, did.

$\mathrm{K} 88+\mathrm{Ent}^{-}$form, although ill when killed, had never had diarrhoea; high concentrations of the infecting organisms were proliferating in its small intestine. E. coli were not found in the livers and spleen of any of the piglets. 
The results of giving the four different forms to colostrum-deprived piglets were essentially the same as those obtained in the naturally reared piglets. Within $12 \mathrm{hr}$, all of seven piglets given the $\mathrm{K} 88+$ Ent ${ }^{+}$form and three of five given the $\mathrm{K} 88+$ Ent - form developed diarrhoea, its severity being greatest in the $\mathrm{K} 88^{+}$Ent + group; none of seven given the $\mathrm{K} 88^{-}$Ent $^{-}$form and none of five given the K88- Ent + form did. All the piglets were killed and examined within $24 \mathrm{hr}$ of infection. Very high concentrations of the infecting organisms were found in the small-intestinal contents of the piglets given the $\mathrm{K} 88+\mathrm{Ent}+$ and $\mathrm{K} 88+\mathrm{Ent}$ - forms and comparatively low ones in those given the K88 - Ent + and the K88-Ent - forms. No organisms were isolated from their livers or spleens. Twelve of these piglets, all from the same litter, had been given $1.0 \mathrm{ml}$ of a broth culture of the nalidixic acid-resistant mutant of the O9:K36:H19 strain at the same time as 0.1 or $0.01 \mathrm{ml}$ of a broth culture of one or other of the four plasmid-containing forms that were streptomycin-resistant. They were killed $12 \mathrm{hr}$ later when all three given the $\mathrm{K} 88+\mathrm{Ent}+$ form, and one of the three given the $\mathrm{K} 88+$ Ent - form, had diarrhoea; the results of the bacteriological examinations on eight of them are shown in table IX. The ratio of nalr to str $\mathrm{r}$ $E$. coli organisms in the stomach contents broadly resembled the ratio in which they had been administered. The ratio was also somewhat similar in the smalland large-intestinal contents of the piglets given the $\mathrm{K} 88^{-}$Ent ${ }^{-}$and $\mathrm{K} 88^{-}$Ent ${ }^{+}$ forms. The situation was quite different in the piglets given the K88+Ent+ and $\mathrm{K} 88+{ }^{+} \mathrm{Ent}^{-}$forms. In their small-intestinal contents, the $\operatorname{str}^{\mathrm{r}}$ organisms greatly out-numbered the $n a l^{\mathrm{r}}$ ones. The concentration of nal $\mathrm{r}$ organisms in the large intestine of these piglets, however, was greater than that of the $s t r^{\mathrm{r}}$ organisms, a consequence of colonisation of this organ occurring before the $s t^{\mathrm{r}}$ organisms proliferated in the small intestine. For the first $12 \mathrm{hr}$ or so of life, the $p \mathrm{H}$ of the stomach contents of piglets is sufficiently high to permit proliferation of $E$. coli in them, with subsequent flooding into the small intestine (Smith and Jones). This probably accounted for the high concentration of $E$. coli found in the stomach contents of some of the piglets in the present experiment with the consequent masking of the full extent of the difference between ${\mathrm{K} 88^{+}}^{+}$and $\mathrm{K} 88^{-}$organisms in regard to ability to proliferate in the small intestine. The two piglets given ten times more nalr organisms than $\mathrm{K} 88+$ Ent $+\operatorname{str}^{\mathrm{r}}$ organisms illustrate this point. The results for one with high concentrations of $E$. coli organisms in the stomach contents are given in table IX. In the other, the concentration of each of the two kinds of organisms in the stomach contents was only $5 \times 10^{4}$ per g. The concentrations of the nal $\mathrm{r}$ organisms per $\mathrm{g}$ in portion $1,3,5$ and 7 of the small intestine were $(2 \cdot 5,25$, 25 and 80$) \times 10^{3}$ respectively, whereas those of the $\operatorname{str}^{\mathrm{r}}$ organisms were $(4,2$, $6 \cdot 3$ and $2 \cdot 5) \times 10^{7}$ respectively.

The effect of introducing $K 88$ and Ent plasmids into a non-pathogenic $O ?: K$ ? $E$. coli strain on its ability to infect pigs

A 24-hr broth culture of a streptomycin-resistant mutant of an untypable non-pathogenic porcine strain of $E$. coli into which Ent, K88ac and Hly plasmids 


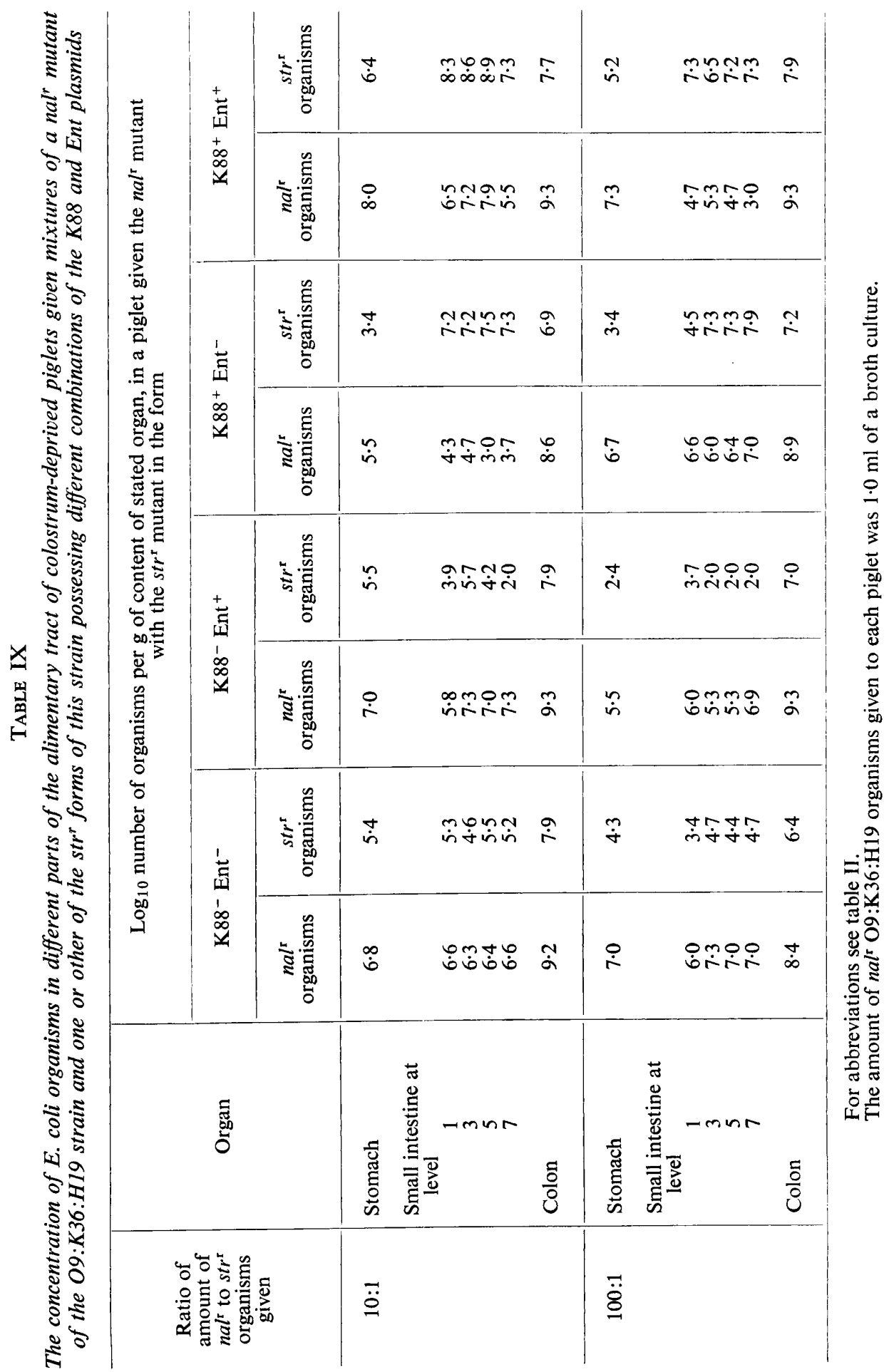


had been introduced was given by mouth to three colostrum-deprived piglets in doses of $1 \cdot 0,0 \cdot 1$ or $0.01 \mathrm{ml}$. The piglets receiving the two lower doses were also given $1.0 \mathrm{ml}$ of a broth culture of an $\mathrm{Hly}-\mathrm{Ent}-\mathrm{K} 88$ - nalidixic acidresistant mutant of this $\mathrm{O}$ ?:K ? strain. The two piglets given the 1.0 or $0.1 \mathrm{ml}$ dose of the $s^{\mathrm{r}}{ }^{\mathrm{r}}$ organisms developed diarrhoea that was less severe than that observed in the colostrum-deprived piglets in the previous experimental pigs given a similar form of the $09: \mathrm{K} 36: \mathrm{H} 19$ strain. The piglet given the 0.01 dose, and two colostrum-deprived piglets given 0.1 or $0.01 \mathrm{ml}$ of a broth culture of an $\mathrm{Hly}+\mathrm{Ent}-\mathrm{K} 88-$ form of the $\operatorname{str}^{\mathrm{r}}$ mutant mixed with $1.0 \mathrm{ml}$ of a

TABLE X

The concentration of $E$. coli organisms in different parts of the alimentary tract of colostrumdeprived piglets given mixtures of a nal mutant of the $O$ ?:K? strain and one or other of the str ${ }^{r}$ forms of this strain possessing different combinations of the K88 and Ent plasmids

\begin{tabular}{|c|c|c|c|c|}
\hline \multirow{3}{*}{ Organ } & \multicolumn{4}{|c|}{$\begin{array}{l}\log _{10} \text { number of organisms per } g \text { of content of stated organ, } \\
\text { in a piglet given the nalr mutant with the } s t r^{\mathrm{r}} \text { mutant in the form }\end{array}$} \\
\hline & \multicolumn{2}{|c|}{ K88- Ent ${ }^{-}$} & \multicolumn{2}{|c|}{$\mathrm{K}^{8} 8^{+} \mathrm{Ent}^{+}$} \\
\hline & nalr organisms & $s t r^{\mathrm{r}}$ organisms & nal ${ }^{r}$ organisms & $s t r^{\mathrm{r}}$ organisms \\
\hline Stomach & $4 \cdot 7$ & $3 \cdot 0$ & $6 \cdot 0$ & $5 \cdot 3$ \\
\hline $\begin{array}{c}\text { Small intestine at level } \\
1 \\
3 \\
5 \\
7\end{array}$ & $\begin{array}{l}5 \cdot 7 \\
4 \cdot 8 \\
6 \cdot 6 \\
7 \cdot 6\end{array}$ & $\begin{array}{l}3 \cdot 5 \\
2 \cdot 6 \\
5 \cdot 3 \\
6 \cdot 4\end{array}$ & $\begin{array}{l}6 \cdot 5 \\
7 \cdot 6 \\
7 \cdot 3 \\
7 \cdot 5\end{array}$ & $\begin{array}{l}5 \cdot 4 \\
5 \cdot 5 \\
9 \cdot 3 \\
8 \cdot 5\end{array}$ \\
\hline Colon & $9 \cdot 5$ & $8 \cdot 8$ & $7 \cdot 8$ & $9 \cdot 3$ \\
\hline
\end{tabular}

For abbreviations see table II.

The piglets were given $1.0 \mathrm{ml}$ of a broth culture of the $n a l^{\mathbf{r}}$ organisms and $0.1 \mathrm{ml}$ of a similar culture of the str $^{\mathrm{r}}$ organisms.

broth culture of the nalr mutant remained healthy. The results of estimating the concentrations of $E$. coli organisms in the two piglets given $1.0 \mathrm{ml}$ of the $n a l^{\mathrm{r}}$ culture and $0.1 \mathrm{ml}$ of the Ent $+\mathrm{K} 88+$ or the Ent $-\mathrm{K} 88-\operatorname{str}^{\mathrm{r}}$ culture (table X) resembled those obtained in similar experiments with the O9:K36:H19 strain (table IX). The selective proliferation of the Ent $+\mathrm{K} 88+$ organisms was confined to the lower half of the small intestine; this was the probable reason for the relative mildness of the diarrhoea.

The effect of the K88 and Hly plasmids on the virulence of

E. coli for mice

The effect of giving groups of mice, intraperitoneally, diluted 18-hr broth cultures of the four forms of the O141:K85ab,88ab strain possessing different 
combinations of the K88 and Hly plasmids is summarised in table XI; the nutrient broth used was unsuitable for the production of $\alpha$-haemolysin. All the deaths occurred within 12 to $48 \mathrm{hr}$ of inoculation, large numbers of the infecting organisms being found in the blood. The Hly plasmid increased the virulence of the organisms containing it and the K88 plasmid decreased it. In additional experiments, the introduction of a $\mathrm{K} 88$ plasmid from an $\mathrm{O} 8: \mathrm{K} 87,88 \mathrm{ab}$ strain into the $\mathrm{Hly}+\mathrm{K} 88$ - form reduced its virulence to that of the $\mathrm{Hly}+\mathrm{K} 88+$ form. The introduction of an Hly plasmid into the Hly- K88- form from a nonpathogenic strain of E. coli, strain P316, increased its virulence beyond that of the Hly $+\mathrm{K} 88$ - form shown in table XI; all of five mice given an injection of

\section{TABLE-XI}

The effect of injecting intraperitoneally into mice forms of the O141:K85ab,88ab strain of Escherichia coli possessing different combinations of the Hly and K88 plasmids

\begin{tabular}{|c|c|c|c|c|}
\hline \multirow{2}{*}{$\begin{array}{l}\text { Dose of viable } \\
\text { organisms }\left(10^{6}\right)\end{array}$} & \multicolumn{4}{|c|}{ Number of mice that died/number of mice given the } \\
\hline & $\mathrm{Hly}^{+} \mathrm{K} 88^{+}$form & $\mathrm{Hly}^{-} \mathrm{K}^{8} 8^{+}$form & $\mathrm{Hly}^{+} \mathrm{K} 88^{-}$form & $\mathrm{Hly}^{-} \mathrm{K}_{88^{-}}^{-}$form \\
\hline $\begin{array}{r}3 \\
5 \\
10 \\
30 \\
100\end{array}$ & $\begin{array}{l}\ldots \\
\dddot{3} / 10 \\
6 / 10 \\
5 / 5\end{array}$ & $\begin{array}{l}\ldots \\
\ldots / 10 \\
0 / 10 \\
1 / 20 \\
8 / 10\end{array}$ & $\begin{array}{c}0 / 5 \\
2 / 5 \\
10 / 10 \\
\ldots \\
\ldots\end{array}$ & $\begin{array}{c}\ldots \\
\dddot{0} \\
0 / 10 \\
11 / 20 \\
10 / 10\end{array}$ \\
\hline
\end{tabular}

$3 \times 10^{6}$ viable organisms, and three of five given $1 \times 10^{6}$ of this new Hly $+\mathrm{K} 88^{-}$ form died. Because of this finding the Hly plasmid from P316, from the original O141:K85ab,88ab strain, and from an enteropathogenic O138:K81 strain of $E$. coli were transmitted to an $\mathrm{O} 18: \mathrm{K}$ ? strain, and the virulence for mice of the three $\mathrm{Hly}^{+}$strains and the $\mathrm{Hly}^{-}$parent strain compared. None of 35 mice infected with $10^{7}$ viable organisms of the $018: \mathrm{K}$ ? Hly - parent strain died. The corresponding figure for the forms that had acquired Hly from P316, O141:K85ab,88ab and the O138:K81 strains were 21, 13 and 3 respectively. When the dose was increased to $3 \times 10^{7}$ organisms, three of five mice infected with the $\mathrm{Hly}^{-}$parent strain died and so did all those infected with the other forms. In in-vitro tests performed by the method of Smith (1963), the O18:K? strain that had acquired Hly from P316 produced only 0.25 times the amount of filterable haemolysin produced by the other two $018: \mathrm{K}$ ? Hly ${ }^{+}$ forms.

No difference was found between the numbers of $\mathrm{Hly}^{+}$and Hly - organisms isolated from the liver, spleen, blood and peritoneal fluid of mice that died after the intraperitoneal injection of equal numbers of organisms of the $\mathrm{O} 18: \mathrm{K}$ ? Hly- strain and of organisms of this strain after the Hly plasmid had been introduced into it from P316. 


\section{The effect of the K88 plasmid on the virulence of Salmonella typhimurium and S. choleraesuis}

S. typhimurium. All of 25 mice given, by mouth, $10^{9}$ viable organisms of a strain of $S$. typhimurium into which a K88ac plasmid had been introduced from an enteropathogenic strain of $E$. coli remained well. When killed 14 days later, none was found to have lesions characteristic of salmonella infection in its liver. In two identical experiments, one in which the original $\mathrm{K} 88^{-}$form of the $S$. typhimurium strain was tested and the other in which the $\mathrm{K} 88+\mathrm{K} 88$ form, i.e., the $\mathrm{K} 88$ + form after removal of the $\mathrm{K} 88$ plasmid, was tested, all the mice became ill and six in each group died; several of the survivors had liver lesions when killed at the end of the experiment.

The above experiment, using the $\mathrm{K} 88{ }^{+}$and the $\mathrm{K} 88+\mathrm{K} 88$ - forms, was repeated, one mouse from each group being killed each day and the concentrations of viable salmonella organisms in the liver, spleen, small intestine and caecum estimated. Only low concentrations of these organisms were found in these sites in the mice killed on the first 3 days. From the 3rd to the 10th day, high concentrations, in the region of $10^{7}$ per $\mathrm{g}$, were found in all four sites in the mice given the $\mathrm{K} 88+\mathrm{K} 88$ - form. By contrast, only low concentrations, $10^{2}-10^{4}$, were found in these sites in the mice given the $\mathrm{K} 88+$ form. A few organisms that had spontaneously lost their K88 plasmid were occasionally isolated from the mice given the $\mathrm{K} 88^{+}$form. Two mice given this form died; the dominant organisms isolated from them were $\mathrm{K} 88^{-}$.

When 15 mice were given an intraperitoneal injection of $10^{3}$ viable organisms of the $\mathrm{K} 88+\mathrm{K} 88$ - form, 12 died. In a similar experiment with the $\mathrm{K} 88$ + form, two died. The numbers of mice that died in groups of five given either $10^{4}, 10^{5}, 10^{6}$ or $10^{7}$ viable organisms of this $\mathrm{K} 88+$ form were $3,4,4$ and 5 respectively. The organisms isolated from the livers of these mice and from the two given $10^{3}$ viable organisms had lost the K88 plasmid.

A $\mathrm{K} 88+\mathrm{K} 88$ - form of another strain of $S$. typhimurium was given, by mouth, to 15 mice; 12 died. Seven of a similar-sized group given the K88+ form died. From the livers of two of these mice, only $\mathrm{K} 88^{+}$organisms were isolated; only organisms that had lost their K88 plasmid were isolated from the other five.

S. choleraesuis. As in the case of S. typhimurium, S. choleraesuis organisms containing the $\mathrm{K} 88$ plasmid were less virulent for mice than were $\mathrm{K} 88^{-}$ones. For example, 4 of 25 mice given, by mouth, $10^{9}$ viable organisms of a strain of $S$. choleraesuis to which the K88ac plasmid had been transmitted from an enteropathogenic strain of $E$. coli died; only $\mathrm{K}^{2} 8^{+}$organisms were isolated from the livers of these four mice. In a similar experiment in which the mice were given the $\mathrm{K} 88+\mathrm{K} 88$ - form of this strain, 16 died.

The $\mathrm{K} 88+$ and the $\mathrm{K} 88+\mathrm{K} 88-$ forms of the $S$. choleraesuis strain were each given, by mouth, in doses of 1010 viable organisms, to 20 pigs, $1-2 \mathrm{wk}$ after they had been weaned when 8 wk of age. As evidenced by clinical signs, including the degree and duration of pyrexia, inappetence and diarrhoea, the disease appeared rather more severe in the group given the $\mathrm{K} 88+\mathrm{K} 88$ - form; 
none of the pigs died. In the 14 days after infection, the pigs given the $\mathrm{K} 88+$ form gained from $-2 \cdot 5$ to $+10 \mathrm{~kg}$ (median $+5 \mathrm{~kg}$ ). The corresponding figure for those given the $\mathrm{K} 88+\mathrm{K} 88$ - form was -7 to $+14 \mathrm{~kg}$ (median $+2 \cdot 5 \mathrm{~kg}$ ).

\section{Discussion}

The results demonstrate the essential part played by the K88 plasmid in determining enteropathogenicity in the wild $0141: \mathrm{K} 85 \mathrm{ab}, 88 \mathrm{ab}$ and $\mathrm{O} 8: \mathrm{K} 40$, 88ab:H9 strains of Escherichia coli and in the non-pathogenic O9:K36:H19 strain that was rendered enteropathogenic by introducing plasmids into it. The bacteriological examination of piglets given $\mathrm{K} 88^{+}$and $\mathrm{K} 88^{-}$forms of these strains indicated that possession of this plasmid was importantly involved in the ability of the organisms to proliferate in the anterior small intestine. The selective manner in which $\mathrm{K} 88^{+}$organisms proliferated in this region was especially noticeable in the experiments in which colostrum-deprived piglets were given forms of the $09: \mathrm{K} 36: \mathrm{H} 19$ strain containing different combinations of plasmids together with larger numbers of a plasmid-free form of this strain from which they could easily be differentiated on the basis of antibiotic sensitivity. Particularly as there was little evidence of invasiveness, even in the colostrum-deprived piglets, it seems probable that the K88 antigen in some manner permitted the organisms to adhere to the epithelium of the small intestine where they multiplied, instead of being carried along with the normal movement of the chyme as the K88 - ones appeared to be. Evidence supporting the view that porcine enteropathogenic $E$. coli organisms do adhere to the epithelium has been provided by Smith and Halls (1968b) and Arbuckle (1970). It is noteworthy, too, that Stirm et al. (1967), in their original observations on K88 antigen, showed by transmission studies that it conferred adhesive properties on organisms, especially haemagglutinating properties. Alternatively, $\mathrm{K} 88^{+}$and $\mathrm{K} 88^{-}$organisms may not differ in their capacity to adhere to the epithelium, but the K $88{ }^{+}$antigen may have a protective function that permits organisms once adherent to proliferate. Certainly, the transmission of the K88 plasmid to salmonellae was not found to confer either protective or, for that matter, adhesive properties; the reverse appeared to be the case. For example, much lower concentrations of salmonellae were found in the alimentary tract, albeit of mice, after oral infection with $\mathrm{K} 88^{+}$than after infection with $\mathrm{K} 88^{-}$- organisms; a similar situation might well have existed in the pigs infected orally with Salmonella choleraesuis since the disease was milder in those given $\mathrm{K} 88$ + organisms. It is probable that the lower virulence of the K88+ forms of the salmonella strains is associated directly with their K88 antigen production and not that organisms that received the K88 plasmid in the transmission studies were initially less virulent than the majority of the organisms forming the parent strain. This latter possibility was overcome by comparing the virulence of the $\mathrm{K} 88^{+}$strains not only with the $\mathrm{K} 88^{-}$parent strains but also with the $\mathrm{K} 88^{+}$strain itself after removal of the plasmid. It appears then that in the salmonella infections, and indeed in the mouse intraperitoneal infections with the enteropathogenic O141:K85ab,88ab strain of E. coli, 
the $\mathrm{K} 88^{+}$organisms are always at a disadvantage compared with $\mathrm{K} 88^{-}$ organisms. It is only in infections of the porcine alimentary tract that possession of the K88 plasmid by the infecting $E$. coli organisms becomes of paramount importance. Even so, some porcine enteropathogenic strains, including the wild $0141: \mathrm{K} 85 \mathrm{ac}$ strain used in the present studies, do not possess the K88 antigen. Neither do those that cause diarrhoea in babies, calves and lambs. These strains evidently must produce other substances that function in the same manner as the $\mathrm{K} 88$ antigen.

The concentrations of organisms in the small intestine of piglets given $\mathrm{K} 88^{-}$Ent ${ }^{+}$forms of $E$. coli were no higher than those in piglets given the corresponding $\mathrm{K} 88$ - Ent - forms, indicating that possession of Ent conferred no advantage on organisms as far as proliferation in this organ is concerned. Ent became important only when the organisms possessing it were proliferating in high concentrations in the small intestine, a consequence of their $\mathrm{K} 88^{+}$ status. There was little doubt that the diarrhoea observed in some of the piglets given $\mathrm{K} 88$ + Ent - forms of the $\mathrm{O} 8: \mathrm{K} 40,88 \mathrm{ab}, \mathrm{H} 9$ and $\mathrm{O} 9: \mathrm{K} 36: \mathrm{H} 19$ strains was the direct result of their presence in high concentration in the small intestines of these piglets. A close association of the organisms with the epithelium was probably important in this respect, since chyme containing high concentrations of non-pathogenic $E$. coli flows through the small intestine of all piglets during the first 12 or so hours of life without causing any apparent harm (Smith and Jones, 1963). The incidence and severity of the diarrhoea in the piglets given the $\mathrm{K} 88$ + Ent - forms, however, were considerably less than in those given the $\mathrm{K} 88+\mathrm{Ent}+$ forms; in ordinary farming practice it might well not cause concern. A situation possibly comparable was observed by Smith and Gyles (1970) after the oral administration of cell-free lysates of Ent ${ }^{+}$and Ent - forms of the same $E$. coli strain in piglets; very severe diarrhoea occurred in 12 of 14 piglets given the Ent + lysate, and mild diarrhoea occurred in 2 of 14 given the Ent - lysate.

The presence of an Hly plasmid in an $E$. coli strain usually increased its virulence for mice on intraperitoneal injection, but the increase varied according to the plasmid introduced. For example, little or no increase accompanied the introduction of the plasmid from the $0138: \mathrm{K} 81$ strain into the $018: \mathrm{K}$ ? strain, an observation in agreement with earlier ones made by Smith and Halls (1967). However, a considerable increase accompanied the introduction of the plasmid from the P316 strain into both the O18:K ? strain and the Hlyform of the O141:K85ab,88ab strain. This Hly+ form of the O18:K? strain produced distinctly less haemolysin than did the less virulent Hly ${ }^{+}$ form of this strain that had received its Hly plasmid from the 0138:K81 strain. These results indicate that Hly plasmids resemble Ent plasmids (Smith and Gyles) in differing from each other to a certain extent. Despite the results of the mouse experiments, and certainly as far as the O141:K85ab,88ab strain was concerned, there was no evidence that the Hly plasmid played any part in the pathogenesis of $E$. coli diarrhoea. Both in the piglets and the weaned pigs, the incidence and severity of the experimental disease were the same in animals given the $\mathrm{Hly}^{+}$form as in those given the Hly-form. The 
bacteriological examination of the alimentary tract of the pigs given mixtures of cultures of the $\mathrm{Hly}^{+}$and $\mathrm{Hly}$ - forms revealed no difference between the two in regard to ability to proliferate in the small intestine. Moreover, the Hly form of the O141:K85ac strain, like the Hly + form, produced oedema disease in addition to diarrhoea. Why then such a high proportion of porcine enteropathogenic strains of $E$. coli are $\alpha$-haemolytic remains a mystery.

By plasmid transmission, the non-pathogenic O9:K36:H19 strain was " converted" into a form which, experimentally, produced a disease in naturally reared piglets indistinguishable from that produced by wild enteropathogenic strains of $E$. coli. Although it was not as virulent as the wild $0141: \mathrm{K} 85 \mathrm{ab}$, $88 \mathrm{ab}$ strain, which experimentally produced very severe diarrhoea in piglets, it might well be able to produce clinical disease under natural conditions. This could not be said for the " converted " $\mathrm{O}$ ?: $\mathrm{K}$ ? strain, which experimentally produced only a mild diarrhoea, and that in colostrum-deprived piglets. Some wild enteropathogenic strains may have been created in nature in the same way as the "converted" $\mathrm{O} 9: \mathrm{K} 36: \mathrm{H} 19$ strain was made in the laboratory. Although possession of the Ent and Hly plasmids has no obviously apparent survival value, that of the $\mathrm{K} 88$ plasmid has, since it enables organisms to colonise the porcine small intestine, a region that normally contains relatively few bacteria. So has the possession of antibiotic-resistance determinants in an antibiotic-containing environment. Since the transfer factors of K88, Ent, Hly and antibiotic-resistance determinants can be common to all these plasmids, it is interesting to speculate whether " new" enteropathogenic strains of $E$. coli will emerge at a more rapid rate in the present antibiotic era than hitherto.

\section{SUMMARY}

Strains of Escherichia coli containing different combinations of the transmissible plasmids governing production of $\alpha$-haemolysin (Hly), enterotoxin (Ent) and K88 antigen (K88) were prepared by the selective addition or removal of these plasmids and tested for ability to produce diarrhoea when given orally to naturally reared piglets and to recently weaned pigs.

The removal of the K88 plasmid from an O141:K85ab,88ab strain was accompanied by the loss of its diarrhoea-producing capacity. It was restored by introducing a $\mathrm{K} 88$ plasmid from another strain of E. coli. The removal of the Hly plasmid had no observable effect. Neither did its removal from another wild enteropathogenic strain of antigenic formula O141:K85ac; the Hlyform of this strain, like the $\mathrm{Hly}^{+}$form, produced oedema disease in addition to diarrhoea.

As a consequence of receiving an Ent plasmid, a non-haemolytic O8:K40, $88 \mathrm{ab}: \mathrm{H} 9$ strain produced diarrhoea more frequently and more severely in piglets than hitherto; after the removal of the K88 plasmid it became nonenteropathogenic.

A non-pathogenic $09: \mathrm{K} 36: \mathrm{H} 19$ strain was rendered enteropathogenic by the introduction of plasmids. The $\mathrm{K} 88+\mathrm{Ent}+$ form produced moderately severe diarrhoea in piglets. A smaller proportion of those given the $\mathrm{K} 88+$ 
Ent ${ }^{-}$form developed a milder diarrhoea. The $\mathrm{K}_{88}-\mathrm{Ent}^{+}$and the K88- Ent ${ }^{-}$ forms had no observable ill-effect.

Bacteriological examinations on the animals given the different forms of the $\mathrm{O} 141: \mathrm{K} 85 \mathrm{ab}, 88 \mathrm{ab}$, the $\mathrm{O} 8: \mathrm{K} 40,88 \mathrm{ab}: \mathrm{H} 9$ and the $\mathrm{O} 9: \mathrm{K} 36: \mathrm{H} 19$ strains revealed that it was the K88 antigen that enabled the organisms to proliferate high up in the small intestine, an essential prerequisite in the pathogenesis of E. coli diarrhoea. The Ent plasmid appeared to play no part in this proliferation, only in the diarrhoea that followed.

The introduction of Hly into strains of $E$. coli was usually accompanied by an increase in virulence for mice challenged intraperitoneally, the extent of the increase varying according to the particular Hly plasmid introduced. Virulence was not related directly to haemolytic activity.

$\mathrm{K} 88+$ forms of strains of $E$. coli were less virulent for mice on intraperitoneal injection than were the corresponding $\mathrm{K} 88$ - forms. So were $\mathrm{K} 88^{+}$forms of Salmonella typhimurium and $S$. choleraesuis after intraperitoneal and oral infection; the $\mathrm{K} 88^{+}$organisms were less able to survive in the alimentary tract and in the tissues than were the $\mathrm{K} 88$ - ones. A K88+ form of $S$. choleraesuis was also less virulent for pigs than was the corresponding $\mathrm{K} 88^{-}$- form.

We are grateful to Miss Marion White, Miss Diane Poulton and Miss Carole Smith for their capable technical help and to Mr L. Abbott, Mrs G. Fage, Dr Ida Ørskov, Dr B. Rowe, $\mathrm{Dr}$ K. C. Sellers and Mr W. J. Sojka for help and assistance in a variety of ways. The expenses of this work were kindly defrayed by a grant from the Agricultural Research Council.

\section{REFERENCES}

Arbuckle, J. B. R. 1970. The location of Escherichia coli in the pig intestine. J. Med. Microbiol., 3, 333.

Bouanchaud, D. H., Scavizzi, M. R., ANd Chabbert, Y. A. 1968. Elimination by ethidium bromide of antibiotic resistance in enterobacteria and staphylococci. J. Gen. Microbiol., 54, 417.

HiRota, Y. 1960. The effect of acridine dyes on mating type factors in Escherichia coli. Proc. Natn. Acad. Sci. USA, 46, 57.

Miles, A. A., MisRa, S. S., AND IRwin, J. O. 1938. The estimation of the bactericidal power of the blood. J. Hyg., Camb., 38, 732.

Moon, H. W., AND WHipp, S. C. 1970 . Development of resistance with age by swine intestine to effects of enteropathogenic Escherichia coli. J. Infect. Dis., 122, 220.

ØRSKOV, IDA, AND ØRSKov, F. 1966. Episome-carried surface antigen K88 of Escherichia coli. 1. Transmission of the determinant of the $\mathrm{K} 88$ antigen and influence on the transfer of chromosomal markers. J. Bact., 91, 69.

SMITH, H. W. 1962. Observations on the aetiology of neonatal diarrhoea (scours) in calves. J. Path. Bact., 84, 147.

SмIтн, H. W. 1963. The haemolysins of Escherichia coli. J. Path. Bact., 85, 197.

SMITH, H. W., AND Gyles, C. L. 1970. The relationship between two apparently different enterotoxins produced by enteropathogenic strains of Escherichia coli of porcine origin. J. Med. Microbiol., 3, 387.

Smith, H. W., AND Halls, Sheila 1967. The transmissible nature of the genetic factor in Escherichia coli that controls haemolysin production. J. Gen. Microbiol., 47, 153.

Smith, H. W., AND Halls, Sheila 1968a. The transmissible nature of the genetic factor in Escherichia coli that controls enterotoxin production. J. Gen. Microbiol., 52, 319. 
Smith, H. W., AND Halls, SheIla 1968b. The production of oedema disease and diarrhoea in weaned pigs by the oral administration of Escherichia coli: factors that influence the course of the experimental disease. J. Med. Microbiol., 1, 45.

SMITH, H. W., AND JoNES, J. E. T. 1963. Observations on the alimentary tract and its bacterial flora in healthy and diseased pigs. J. Path. Bact., 86, 387.

STIRM, S., ØrSkov, F., ØRskov, IDA, AND BIRCH-ANDERSEN, A. 1967. Episome-carried surface antigen K88 of Escherichia coli. III. Morphology. J. Bact., 93, 740.

Tomoeda, M., INUzuKA, M., KUBO, N., AND NAKAMURA, S. 1968. Effective elimination of drug resistance and sex factors in Escherichia coli by sodium dodecyl sulphate. J. Bact., 95, 1078.

Watanabe, T. 1963. Infective heredity of multiple drug resistance in bacteria. Bact. Rev., 27, 87. 